\title{
VIEWPOINT
}

\section{BRCA1 as a tumor suppressor linked to the regulation of epigenetic states: keeping oncomiRs under control}

\author{
Olafur Andri Stefansson ${ }^{1}$ and Manel Esteller ${ }^{* 1,2,3}$
}

\begin{abstract}
BRCA1 is a tumor suppressor gene known to be implicated in the development of a subset of breast and ovarian cancers. The tumor suppressor properties of $B R C A 1$ are generally thought to be linked to the gene's critical roles in the network of DNA damage response. In a recent report, BRCA1-mediated epigenetic repression at the promoter region of miRNA-155 was identified as a novel mechanism by which BRCA1 carries out its tumor suppressor functions.
\end{abstract}

\section{Background}

Inherited mutations in $B R C A 1$ greatly increase the risk of breast cancer [1]. Tumors arising in mutation carriers have generally lost the wild-type $B R C A 1$ allele [2]. These findings have led to the definition of BRCA1 as a tumor suppressor. The BRCA1 gene has well-established roles in maintenance of genomic integrity, including DNA repair by homologous recombination, DNA decatenation, and regulation of centrosomes [3]. In accordance, extensive changes in chromosome structure and number are observed in tumors derived from carriers [4,5]. The tumor suppressor functions of BRCA1 are therefore commonly attributed to its role in genomic maintenance. The BRCA1 gene has other roles, however, including those related to cellular differentiation and transcriptional regulation.

miRNAs are small noncoding RNAs ( 22 nucleotides) that mediate post-transcriptional gene silencing by controlling the translation of mRNA into protein products [6]. In cancer, miRNAs are differentially expressed when compared with the corresponding normal tissue, and

${ }^{*}$ Correspondence: mesteller@idibell.cat

${ }^{1}$ Cancer Epigenetics and Biology Program (PEBC), Bellvitge Biomedical Research Institute (IDIBELL), 08908 L'Hospitalet, Barcelona, Catalonia, Spain

Full list of author information is available at the end of the article some have tumor suppressor properties whereas others are oncogenic (so-called oncomiRs) [7,8]. In a recent report, Chang and colleagues identified a novel role for BRCA1 as an important mediator of epigenetic repression of an oncomiR; that is, miRNA-155 [9].

\section{The article}

Change and colleagues report substantial differences in the ability of $\mathrm{R} 1669 \mathrm{Q}$, a BRCA1 mutation currently of unknown clinical significance (single amino-acid substitution), to rescue lethality of Brca1-null ES cells compared with wild-type BRCA1 [9]. The functional assays carried out suggest a significant role for the R1699Q mutation in tumor suppression. Nevertheless, R1699Qexpressing embryonic stem cells (Brca1 null) were not sensitive to DNA-damaging agents and did not show genomic instability. This finding is interesting, given the critical role carried out by BRCA1 gene products in the cellular response to DNA damage.

Using microarrays, high expression of miRNA-155 was found in R1699Q cells and was validated in further experiments. The BRCA1 binding site was identified, and validated, at the promoter region of miRNA-155. The authors then show that BRCA1 mediates chromatin remodeling at the promoter region of miRNA- 155 through direct protein-protein interactions with histone deacetylase 2 [9]. This was established by experiments involving targeted mutation of promoter binding sites, chromatin immunoprecipitations and inhibition of histone deacetylases. The experiments that followed suggested oncogenic properties in association with miRNA-155, based on ectopic expression in cell lines injected into mice and data in human breast cancer samples showing high miRNA-155 in association with BRCA1 defects.

\section{The viewpoint}

In studying the effects of $B R C A 1 \mathrm{R} 1699 \mathrm{Q}$, a mutation of unknown clinical significance, Chang and colleagues discovered a novel mechanism for BRCA1 as a tumor suppressor gene [9]. This mechanism involves the binding of BRCA1 gene products to the promoter region of 
miRNA-155 (a known oncomiR), where they mediate epigenetic repression through protein-protein interactions with histone deacetylase 2. Interestingly, what emerges from this study is that R1699Q products retain DNA repair activities. In this regard, examining the phenotype of breast cancers arising in R1699Q carriers will be of considerable interest. Together with the analysis of sporadic cancers, with respect to miRNA-155 and basal or stem cell/progenitor markers, this could lead to a better understanding of the development of basallike breast cancers. Clearly, this analysis will involve experimentally validating the targets of miRNA-155, and determining whether there are other genes regulated by this same mechanism - that is, BRCA1-mediated epigenetic repression.

The clinical implications that arise from this research relate to recent progress made in clinical trials showing promising anti-cancer effects from inhibitors of polyADP-ribose polymerase (PARP) in treatment of patients with inherited mutations in BRCA1 or BRCA2 [10]. The effectiveness of PARP inhibitors in this regard relates to loss of the wild-type allele in cancer cells of mutation carriers, resulting in defective DNA repair by homologous recombination [11]. PARP inhibitors will thus probably not be effective in treatment of patients with the R1699Q mutation. In sporadic cases of breast cancer, however, the $B R C A 1$ gene is inactivated by epigenetic mechanisms $[12,13]$ rather than by acquired point mutations [14]. We have previously reported that a substantial fraction of sporadic breast cancers have acquired $\mathrm{CpG}$ island hypermethylation of the BRCA1 gene and that their evolutionary path is similar to breast cancers arising in BRCA1 mutation carriers $[4,12,13,15]$. Most importantly, BRCA1 hypermethylation predicts response to PARP inhibitors at the same level as BRCA1 germline mutations [16]. In this regard, the question arises of whether miRNA-155 can be used as a biomarker to guide treatment selection with respect to PARP inhibitors or DNA-damaging agents. Further, there have been considerable efforts in determining whether circulating miRNAs in blood can be used as biomarkers for early detection of cancer [7] - based on its potential early involvement, miRNA-155 could represent a candidate marker in this respect.

\section{Abbreviations}

miRNA, microRNA; oncomiR, oncogenic microRNA; PARP, poly-ADP-ribose polymerase.

\section{Competing interests}

The authors declare that they have no competing interests.

\section{Author details}

'Cancer Epigenetics and Biology Program (PEBC), Bellvitge Biomedical Research Institute (IDIBELL), 08908 L'Hospitalet, Barcelona, Catalonia, Spain. ${ }^{2}$ Department of Physiological Sciences II, School of Medicine, University of
Barcelona, 08036 Barcelona, Catalonia, Spain. ${ }^{3}$ Institució Catalana de Recerca i Estudis Avançats (ICREA), 08010 Barcelona, Catalonia, Spain.

Published: 16 March 2012

\section{References}

1. Miki Y, Swensen J, Shattuck-Eidens D, Futreal PA, Harshman K, Tavtigian S, Liu Q, Cochran C, Bennett LM, Ding W: A strong candidate for the breast and ovarian cancer susceptibility gene BRCA1. Science 1994, 266:66-71.

2. Smith SA, Easton DF, Evans DG, Ponder BA: Allele losses in the region 17q12-21 in familial breast and ovarian cancer involve the wild-type chromosome. Nat Genet 1992, 2:128-131.

3. Roy R, Chun J, Powell SN: BRCA1 and BRCA2: different roles in a common pathway of genome protection. Nat Rev Cancer 2012, 12:68-78.

4. Stefansson OA, Jonasson JG, Johannsson OT, Olafsdottir K, Steinarsdottir M, Valgeirsdottir S, Eyfjord JE: Genomic profiling of breast tumours in relation to BRCA abnormalities and phenotypes. Breast Cancer Res 2009, 11:R47.

5. Stephens PJ, McBride DJ, Lin ML, Varela I, Pleasance ED, Simpson JT, Stebbings LA, Leroy C, Edkins S, Mudie LJ, Greenman CD, Jia M, Latimer C, Teague JW, Lau KW, Burton J, Quail MA, Swerdlow H, Churcher C, Natrajan R, Sieuwerts AM, Martens JW, Silver DP, Langerod A, Russnes HE, Foekens JA, Reis-Filho JS, van't Veer L, Richardson AL, Borresen-Dale AL, et al: Complex landscapes of somatic rearrangement in human breast cancer genomes. Nature 2009, 462:1005-1010.

6. Esteller M: Non-coding RNAs in human disease. Nat Rev Genet 2011, 12:861-874.

7. Krutovskikh VA, Herceg Z: Oncogenic microRNAs (OncomiRs) as a new class of cancer biomarkers. Bioessays 2010, 32:894-904.

8. Lopez-Serra P, Esteller M: DNA methylation-associated silencing of tumorsuppressor microRNAs in cancer. Oncogene 2011. Epub ahead of print

9. Chang S, Wang RH, Akagi K, Kim KA, Martin BK, Cavallone L, Haines DC, Basik M, Mai P, Poggi E, Isaacs C, Looi LM, Mun KS, Greene MH, Byers SW, Teo SH, Deng CX, Sharan SK: Tumor suppressor BRCA1 epigenetically controls oncogenic microRNA-155. Nat Med 2011, 17:1275-1282.

10. Fong PC, Boss DS, Yap TA, Tutt A, Wu P, Mergui-Roelvink M, Mortimer $P$, Swaisland H, Lau A, O'Connor MJ, Ashworth A, Carmichael J, Kaye SB, Schellens JH, de Bono JS: Inhibition of poly(ADP-ribose) polymerase in tumors from BRCA mutation carriers. N Engl J Med 2009, 361:123-134

11. Ashworth A: A synthetic lethal therapeutic approach: poly(ADP) ribose polymerase inhibitors for the treatment of cancers deficient in DNA double-strand break repair. J Clin Oncol 2008, 26:3785-3790.

12. Esteller M, Silva JM, Dominguez G, Bonilla F, Matias-Guiu X, Lerma E, Bussaglia E, Prat J, Harkes IC, Repasky EA, Gabrielson E, Schutte M, Baylin SB, Herman JG: Promoter hypermethylation and BRCA1 inactivation in sporadic breast and ovarian tumors. J Natl Cancer Inst 2000, 92:564-569.

13. Birgisdottir V, Stefansson OA, Bodvarsdottir SK, Hilmarsdottir H, Jonasson JG, Eyfjord JE: Epigenetic silencing and deletion of the BRCA1 gene in sporadic breast cancer. Breast Cancer Res 2006, 8:R38.

14. Futreal PA, Liu QY, Shattuckeidens D, Cochran C, Harshman K, Tavtigian S, Bennett LM, Haugenstrano A, Swensen J, Miki Y, Eddington K, Mcclure M, Frye C, Weaverfeldhaus J, Ding W, Gholami Z, Soderkvist P, Terry L, Jhanwar S, Berchuck A, Iglehart JD, Marks J, Ballinger DG, Barrett JC, Skolnick MH, Kamb A, Wiseman R: BRCA1 mutations in primary breast and ovarian carcinomas. Science 1994, 266:120-122.

15. Stefansson OA, Jonasson JG, Olafsdottir K, Hilmarsdottir H, Olafsdottir G, Esteller M, Johannsson OT, Eyford JE: CpG island hypermethylation of BRCA1 and loss of pRb as co-occurring events in basal/triple-negative breast cancer. Epigenetics 2011, 6:638-649.

16. Veeck J, Ropero S, Setien F, Gonzalez-Suarez E, Osorio A, Benitez J, Herman JG, Esteller M: BRCA1 CpG island hypermethylation predicts sensitivity to poly(adenosine diphosphate)-ribose polymerase inhibitors. J Clin Oncol 2010, 28:e563-e564.

doi:10.1186/bcr3119

Cite this article as: Stefansson OA, Esteller M: BRCA1 as a tumor suppressor linked to the regulation of epigenetic states: keeping oncomiRs under control. Breast Cancer Research 2012, 14:304. 